Urban Agriculture and City Sustainability II 83

\title{
ASSESSING THE PERFORMANCE OF URBAN GREEN INFRASTRUCTURE: THE CASE STUDY OF BENICALAP DISTRICT, VALENCIA, SPAIN
}

\author{
CARLA M. TUDORIE ${ }^{1}$, MARÍA VALLÉS-PLANELLS ${ }^{2}$, ERIC GIELEN $^{3} \&$ FRANCISCO GALIANA $^{2}$ \\ ${ }^{1}$ Universitat Politècnica de València (UPV), Spain \\ ${ }^{2}$ School of Agricultural Engineering and Environment, Department of Rural and Agrifood Engineering, \\ Universitat Politècnica de València, Spain \\ ${ }^{3}$ School of Civil Engineering, Department of Urbanism, Universitat Politècnica de València, Spain
}

\begin{abstract}
During the last few years, the number of cities which are making efforts in improving urban greenery as a measure to strengthen urban resilience and citizen's wellbeing is increasing. The assessment of the implementation of urban green infrastructure actions, as any other type of intervention, involves the use of indicators to measure the effects of these actions. These indicators are understood as parameters that allow assessing the impact and the temporary monitoring of the effects of human actions carried out on the territory. Drawing on the literature of ecosystem/landscape services and green infrastructure, this study proposes a set of indicators which are able to analyse the performance of urban green infrastructure in terms of structure and functionality. A selection of the proposed indicators connected to structural properties, regulation and cultural landscape services are tested at the street level in Valencia City, Spain. Indicators are applied in two pilot actions which are being developed in Benicalap District, Valencia, in the context of a broader project which aims to give evidence about the benefits of nature-based solutions. This research contributes to a better understanding of how indicators can be used as an effective tool to assess the landscape services provided by urban green infrastructure. This information can be useful to communicate the benefits of urban green infrastructure and to make decisions about the development of sustainable strategies based on urban greenery.

Keywords: nature-based solutions, sustainability, urban greenery, landscape services, Valencia.
\end{abstract}

\section{INTRODUCTION}

Green areas deliver a wide range of landscape services (LS) to face city's challenges and reach resilience and sustainability. Nowadays, there is an increasing concern of the relevance of giving evidences of the benefits offered by green infrastructure [1]-[4], in order to prove that an increase of urban green spaces would provide a proportionally larger number of ecological, economic and social benefits and services. Urban green infrastructure (UGI) includes green, partly green and blue spaces (e.g. wetlands). It also includes green spaces which can be located close to the city or within the city itself, like agricultural land [2].

During the last years, European Commission has shown a growing concern in the role of green infrastructure (GI) and many reports have been developed to help find solutions to urban challenges through the implementation of GI. The Commission has started to pay attention to the need of efficient tools to map GI components, which are thought to support the future landscape services' assessment. Some examples of physical mapping methods are available (e.g. Guidos Toolbox, Conefor software package, Linkage Mapper, Quickscan) and have been deployed to city case studies from the local to pan-European scales [5]. Despite the benefits associated with UGI, implementation is far from straightforward or to be incorporated in applied urban planning and management [6], [7].

Sustainable strategies could be successfully designed and implemented through guiding current and hypothetical results of UGI improvements with the aid of a set of green performance indicators. This research brings knowledge of the impacts of nature-based 
solutions (NBS) related to three urban challenges, which were proposed by EKLIPSE experts [3] to guide the design, development, implementation and assessment of NBS pilot projects in urban and in the climate mitigation context [4].

The main goal of this work is to propose a set of green performance indicators and show how to practically assess the landscape services provided by urban green infrastructure. These examples of urban green infrastructure indicators, adapted to landscape services classification, are applied for the evaluation of environmental and cultural benefits provided by pilot actions in open spaces in Benicalap District, Valencia. Key performance indicators (KPIs) are applied to pre-greening and post-greening stages of Grow Green NBS pilot projects. In particular, this work focuses on the monitoring of two of these actions: a sustainable small forest and a green-blue corridor.

\section{METHODOLOGY}

\subsection{Proposal of urban green indicators}

Considering the relevance of green indicators and urban green infrastructure for urban planning [7], [8], a set of the most mentioned UGI indicators is proposed (Table 1) to be applied at urban level to assess UGI performance.

The proposal of indicators is structured in two parts following the structure-functionvalue chain model proposed by Termorshuizen and Opdam [9]. First, the structure indicators are related to spatially explicit landscape characteristics, which may be connected to more than one landscape service. For instance, large tree diameter generally involves a large tree canopy that promotes stormwater interception, reduction of local temperature and habitat for nesting birds and small mammals. Secondly, the function and value indicators are proposed for assessing the principal regulation and cultural landscape services delivered by UGI. The function indicators refer to the potential or capacity to deliver a service (e.g. runoff coefficient in relation to precipitation quantities or recreation potential) and the value indicators are connected to the benefit, economic or non-economic, for people (e.g. economic benefit of reduction of storm water to be treated in public sewerage system). The functional and value indicators are arranged according to the LS and their subcategories following previous work on indicators, for example, Pakzad and Osmond [8] and Valls-Donderis et al. [10]. LS are classified according to the framework established by Vallés-Planells et al. [11], which was based in the Common International Classification of Ecosystem Services (CICES) [12].

\subsection{Location of nature-based solutions in city of Valencia: \\ Grow Green projects study area}

Benicalap District has 2,216,000 $\mathrm{m}^{2}$ of surface of which $367,038 \mathrm{~m}^{2}$ are urban green infrastructure. The resident population reaches 46,699 inhabitants, around $8 \mathrm{~m}^{2}$ of green spaces per inhabitant [13]. The shortest distance between green spaces is $228 \mathrm{~m}$, which facilitates $62.5 \%$ of inhabitants have access to urban green infrastructure in the very nearby (at $50 \mathrm{~m}$ from their house) and $100 \%$ of Benicalap population further (at $300 \mathrm{~m}, 500 \mathrm{~m}$ distance).

Grow Green project (GG) embeds five NBS-actions [4] in Ciutat Fallera neighbourhood, whose objective is to make citizens aware of the need of sustainability in the cities. Ciutat Fallera and Benicalap are neighbourhoods within Benicalap District (Fig. 1) northwest of the city. These actions seek to restore the ancestral connections and ensure the transition between 
Table 1: Collection of landscape services and green indicators (KPIs) at urban level.

\begin{tabular}{|c|c|c|c|c|}
\hline \multicolumn{5}{|c|}{ GI indicators linked to structural characterization } \\
\hline & Theme & & UGI i & \\
\hline \multirow{2}{*}{ 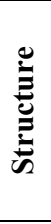 } & $\begin{array}{l}\text { Spatial } \\
\text { structure }\end{array}$ & \multicolumn{3}{|c|}{$\begin{array}{l}\text { Green area/inhabitant, proximity to green spaces, total area of green s } \\
\text { accessibility of urban green, structural and functional connectivity, } \\
\text { impervious surface, facilities }\end{array}$} \\
\hline & $\begin{array}{l}\text { Urban } \\
\text { vegetation } \\
\text { structure }\end{array}$ & \multicolumn{3}{|c|}{$\begin{array}{l}\text { Density of trees by street section, percent of street trees of top most } \\
\text { abundant genus, family and order, tree diameter classes, tree crown } \\
\text { coverage }\end{array}$} \\
\hline \multicolumn{5}{|c|}{ GI indicators linked to regulation and maintenance landscape services } \\
\hline & Class & Group & Subgroup & UGI indicators \\
\hline \multirow{6}{*}{ 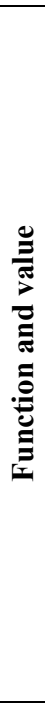 } & $\begin{array}{l}\text { Flow } \\
\text { regulation }\end{array}$ & $\begin{array}{l}\text { Water flow } \\
\text { regulation }\end{array}$ & Runoff regulation & $\begin{array}{l}\text { Runoff coefficient in relation to } \\
\text { precipitation quantities, economic } \\
\text { benefit of reduction of storm water } \\
\text { to be treated in public sewerage } \\
\text { system, flood peak reduction }\end{array}$ \\
\hline & \multirow{3}{*}{$\begin{array}{l}\text { Regulation of } \\
\text { physical } \\
\text { environment }\end{array}$} & \multirow{3}{*}{$\begin{array}{l}\text { Atmospheric } \\
\text { regulation }\end{array}$} & Climate regulation & $\begin{array}{l}\text { Temperature reduction in urban } \\
\text { areas, reduced building energy use } \\
\text { for heating and cooling }\end{array}$ \\
\hline & & & $\begin{array}{l}\text { Climate change } \\
\text { mitigation }\end{array}$ & $\begin{array}{l}\text { Total amount/yearly carbon } \\
\text { sequestration and stored in } \\
\text { vegetation }\end{array}$ \\
\hline & & & $\begin{array}{l}\text { Air quality } \\
\text { regulation }\end{array}$ & $\begin{array}{l}\text { Annual amount of pollutants }\left(\mathrm{O}_{3} \text {, }\right. \\
\left.\mathrm{NO}_{2}, \mathrm{SO}_{2}, \mathrm{PM}_{10}, \mathrm{PM}_{2.5}\right) \text { captured by } \\
\text { vegetation }\end{array}$ \\
\hline & \multirow{3}{*}{$\begin{array}{l}\text { Regulation of } \\
\text { biotic } \\
\text { environment }\end{array}$} & \multirow[b]{2}{*}{$\begin{array}{l}\text { Lifecycle } \\
\text { maintenance } \\
\text { and habitat } \\
\text { protection }\end{array}$} & Noise regulation & Noise level attenuation \\
\hline & & & $\begin{array}{c}\text { Biodiversity } \\
\text { maintenance and } \\
\text { pest and disease } \\
\text { control }\end{array}$ & $\begin{array}{l}\text { Vegetation and wildlife diversity, } \\
\text { habitat heterogeneity, species } \\
\text { suitability }\end{array}$ \\
\hline \multicolumn{4}{|c|}{ GI indicators linked to cultural landscape services } & \\
\hline & Class & Group & Subgroup & UGI indicators \\
\hline \multirow{6}{*}{ 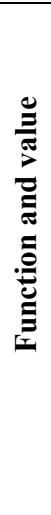 } & Health & $\begin{array}{l}\text { Physical } \\
\text { health }\end{array}$ & & $\begin{array}{l}\text { Walkability, increase of physical } \\
\text { outdoor activity }\end{array}$ \\
\hline & \multirow{3}{*}{ Self-fulfilment } & \multirow[t]{2}{*}{$\begin{array}{l}\text { Mental } \\
\text { health }\end{array}$} & & $\begin{array}{l}\text { Reduced depression and anxiety, } \\
\text { attention restoration, recovery from } \\
\text { stress }\end{array}$ \\
\hline & & & & $\begin{array}{l}\text { Recreation potential, green space } \\
\text { quality, green space attractiveness, } \\
\text { green space visitation }\end{array}$ \\
\hline & & $\begin{array}{l}\text { Didactic } \\
\text { resources }\end{array}$ & & Outdoor educational activities \\
\hline & \multirow[t]{2}{*}{$\begin{array}{l}\text { Social } \\
\text { fulfilment }\end{array}$} & $\begin{array}{l}\text { Social } \\
\text { relationship }\end{array}$ & & $\begin{array}{l}\text { Social interactions, community } \\
\text { activities, social cohesion }\end{array}$ \\
\hline & & $\begin{array}{c}\text { Place } \\
\text { identity }\end{array}$ & & Neighborhood attachment \\
\hline
\end{tabular}

the rural and the urban ecosystems. In Valencia, the urban orchard, Huerta de Valencia, is a unique agroecosystem, declared World Heritage by the UN, and a fundamental component of UGI and maybe a sustainable strategy to tackle climate mitigation. The target actions of 


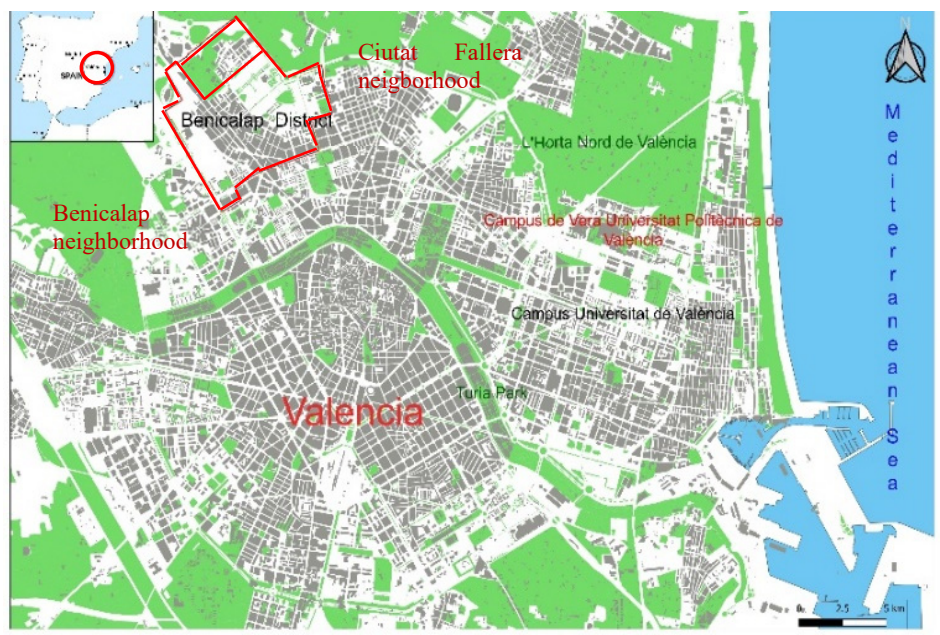

Figure 1: The urban green infrastructure and the location of Benicalap District in Valencia, Spain.

this study are: a green-blue corridor (GG action 3) and a sustainable small forest (GG action 2).

Two sites of Benicalap District are selected for practical assessments (Fig. 2). A street connected to a small square as a part of a corridor and a poor in vegetation-vacant lot of Ciutat Fallera were selected for the location of NBS pilot projects. Four alternatives were assessed to choose the most suitable location for the green-blue corridor (Fig. 2). The sustainable small forest was decided to be created in the neighbourhood of Benicalap park and two farmhouses (Alquería del Moro and Alquería de La Torre).

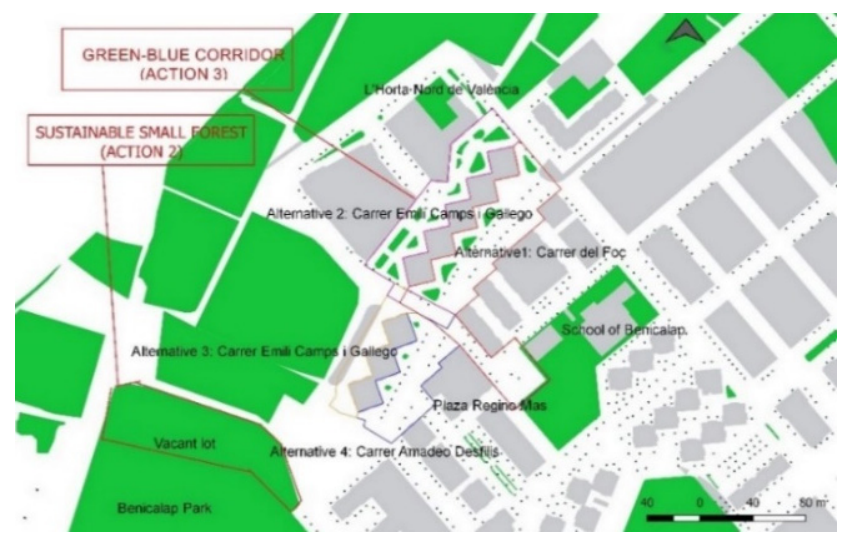

Figure 2: The current state of UGI of Ciutat Fallera, Benicalap, the locations of NBS pilot projects: Sustainable small forest (Action 2) and green-blue corridor (Action 3); Alternative 1: Carrer del Foc and Plaza Regino Mas, Alternative 2: Carrer Emili Camps Gallego (north) and Plaza Regino Mas, Alternative 3: Carrer Emili Camps Gallego (south) and Plaza Regino Mas, Alternative 4: Carrer Amadeo Desfilis and Plaza Regino Mas. 


\subsection{UGI classification: Selection of landscape services provided by UGI to assess}

The most relevant green indicators found in literature are applied to street elements of urban green infrastructure. For this purpose, UGI map is developed with the aid of GIS and fieldwork (Fig. 2). Table 2 shows the UGI street elements included in Nature-based solution pilot projects which were proposed in the context of Grow Green H2020 European project.

Table 2: UGI elements found in pilot projects in Benicalap neighbourhood according to European Union [2], Clément [14] and Valencia City Council [15].

\begin{tabular}{ccl}
\hline $\begin{array}{c}\text { Vegetation } \\
\text { cover }\end{array}$ & UGI & Description \\
\hline $\begin{array}{c}\text { 1. Ruderal } \\
\text { vegetation }\end{array}$ & $\begin{array}{c}\text { Abandoned, } \\
\text { ruderal } \\
\text { areas }\end{array}$ & $\begin{array}{l}\text { Recently abandoned areas, construction sites, etc. } \\
\text { with spontaneously occurring pioneer or ruderal } \\
\text { vegetation. }\end{array}$ \\
\hline \multirow{2}{*}{$\begin{array}{c}\text { Tree alleys } \\
\text { and street } \\
\text { trees, } \\
\text { hedges }\end{array}$} & $\begin{array}{l}\text { Trees having or not having tree pits, planted along } \\
\text { roads and paths either solitary or in rows, trees } \\
\text { surrounding hedges along roads or paths. }\end{array}$ \\
\cline { 2 - 3 } boulevards & Green verge & $\begin{array}{l}\text { Stripes of green, e.g. flowers, along a built or natural } \\
\text { element. }\end{array}$ \\
\cline { 2 - 3 } & Street green & $\begin{array}{l}\text { Non-tree, mostly shrubby or grassy road verges or } \\
\text { areas between the opposite roadways. }\end{array}$ \\
\cline { 2 - 4 } & $\begin{array}{c}\text { Green } \\
\text { island }\end{array}$ & $\begin{array}{l}\text { Sustainable green roundabout, which can contain } \\
\text { flowers, shrubs and trees. }\end{array}$ \\
\hline
\end{tabular}

2.4 Analysis blocks and UGI indicators used for pilot projects assessment

The sequence of urban green infrastructure indicators is shown according to their utility to achieve study's objectives and is structured in three blocks (Table 3):

A. Selection of the most suitable alternative for the green corridor. Four vegetation plan alternatives (Fig. 2) are assessed as possible locations of a green-blue corridor according to UGI biodiversity indicators.

B. Assessment of the impact of the green-blue corridor and the sustainable small forest on regulation and maintenance LS: biodiversity. This block includes current evaluations (pre-greening stage) and future (post-greening stage) of indicators connected to plant community structure and biodiversity to demonstrate the effectiveness of UGI implementation and green indicators' validity.

C. Assessment of the impact of the green-blue corridor and the sustainable small forest on cultural LS. Social interactions and physical activity level are assessed before the implementation of NBS through cultural UGI indicators.

\subsection{Urban vegetation structure indicators description}

The density of trees by street section is a value that relates the number of trees per meter of transverse section. Some minimum criterion of tree density per section are used, so the optimum density for big size trees should be 0.2 [16]. Longitudinal transects along pilot 
projects were done in June 2019. Considering the length of project actions, street section

Table 3: Proposed indicators to assess the performance of the green infrastructure of Benicalap District, Valencia, Spain. The division of indicators is according to their utility case.

\begin{tabular}{|c|c|c|}
\hline Subgroup & UGI indicators & Utility \\
\hline $\begin{array}{l}\text { Urban vegetation } \\
\text { structure }\end{array}$ & $\begin{array}{l}\text { Density of trees by street section, Percent of street trees } \\
\text { of top most abundant genus, family and order, Tree } \\
\text { diameter classes, Crown coverage of the tree (large) } \\
\text { Index of abundance of street trees in pilot projects }\end{array}$ & B \\
\hline $\begin{array}{l}\text { Biodiversity } \\
\text { maintenance and } \\
\text { pest and disease } \\
\text { control }\end{array}$ & $\begin{array}{l}\text { Diversity of trees, shrubs and bushes, diversity of } \\
\text { vegetation strata, Species suitability }\end{array}$ & A, B \\
\hline $\begin{array}{l}\text { Increase of physical } \\
\text { activity }\end{array}$ & $\begin{array}{l}\text { Percentage of people undertaking forms of physical } \\
\text { activity }\end{array}$ & $\mathrm{C}$ \\
\hline $\begin{array}{l}\text { Community } \\
\text { cohesion }\end{array}$ & $\begin{array}{l}\text { Percentage of people interacting with each other in an } \\
\text { outdoor space }\end{array}$ & $\mathrm{C}$ \\
\hline
\end{tabular}

measures $50 \mathrm{~m}$. Tree diameter classes indicator is used to classify green infrastructure trees according to their size class distribution. It is desirable for cities to manage and reach standard values of street trees distribution in UGI elements. Street trees are classified in size classes according to tree diameter breast height (DBH) [17].

Crown coverage is the projected surface of the tree canopy cover that was used to calculate habitat diversity. Performance indicators are proposed to obtain a desirable percentage of existing urban tree canopy by using street trees canopy desired values as proposed by Leff [18].

Index of abundance of street trees is used to evaluate street trees species taxonomic order present in the urban ecosystem. Current species richness of street trees of pilot projects is assessed with UGI map. Information about street trees species is found on the website of Statistical Office of Valencia municipality.

\subsection{Biodiversity}

In order to calculate the biodiversity of trees, shrubs and bushes, Shannon-Wiener Index (H') is used, with the aid of Braun-Blanquet scale [19]. According to Krebs [20], evenness (E) oscillates between 0 (species are not equally distributed) and 1 (there is equal species distribution, complete evenness). Urban green infrastructure diversity of vegetation strata is also estimated with Shannon-Wiener Index based on five different proportions of habitat proposed by Handley [21] to measure the heterogeneity of a habitat: bare ground and turf grass, rough grassland and herbs, shrubs, trees (tree canopy) and built (impervious) environment. Diversity strata index of post-greening moment is an estimation since the real surface covered by new introduced vegetation is uncertain.

Protective tree diversity can be measured with the aid of three indicators: age diversity or age classes considering diameter classes, species diversity and species suitability [18]. Species suitability is understood as their level of adaptation to local climate, fulfil soil, humidity and management's requisites and are not invasive. 


\subsection{Physical activity and social interactions: Mohawk}

Method for observing physical activity and wellbeing, on short Mohawk, proposed by Benton et al. [22] was designed to measure physical activity and social interactions in small urban green space such as: pocket parks, tree-lined streets and green corridors along waterways. In this study, we apply these cultural indicators to assess present situation of pilot projects.

Social interactions were measured with behavioural observations of individuals who are interacting with the people around them. The same person can be coded as engaging in multiple behaviours. Physical health of Ciutat Fallera's inhabitants was assessed with indicators of physical activity level. Physical activity is more than physical exercise [23].

Regarding the adequacy of field observations, data are collected about inhabitants "age and gender and ruled hours" intervals. Pre-greening assessment of neighbourhood wellbeing indicators was carried out during one week on November 2019.

\section{RESULTS AND DISCUSSION}

\subsection{Selection of the most suitable alternative for the green corridor}

The analysis of the four green corridor alternatives (Fig. 2) in terms of biodiversity indicates that alternatives 1 and 2 are the best locations according to biodiversity. This information was used together with data on indicators related to other regulation services (runoff regulation, climate regulation and climate change mitigation), cultural services (recreation potential and place identity) and other factors connected to gender issues in order to decide the best alternative. After this process, alternative 1, Carrer del Foc street and Plaza Regino Mas square, was selected as the best location to build green-blue corridor (Table 4).

Table 4: Results of diversity indices applied to vegetation species and habitat types of proposed alternatives for selecting green-blue corridor emplacement.

\begin{tabular}{llcccc}
\hline & Diversity indices & \multicolumn{4}{c}{ Alternatives } \\
& & $\mathbf{1}$ & $\mathbf{2}$ & $\mathbf{3}$ & $\mathbf{4}$ \\
\hline \multirow{3}{*}{ Vegetation } & Shannon-Wiener Index & $\mathbf{1 . 9 3}$ & 1.98 & 1.76 & 1.71 \\
& Maximum diversity & $\mathbf{3 . 7 8}$ & 3.66 & 3.76 & 3.76 \\
& Evenness & $\mathbf{0 . 5 1}$ & 0.54 & 0.47 & 0.45 \\
& Shannon-Wiener Index & $\mathbf{0 . 9 9}$ & 1.07 & 0.94 & 0.98 \\
& Maximum diversity & $\mathbf{1 . 6 1}$ & 1.61 & 1.61 & 1.61 \\
& Evenness & $\mathbf{0 . 6 1}$ & 0.66 & 0.59 & 0.61 \\
& Bare ground/turf grass & $\mathbf{9 . 1 8}$ & 12.67 & 9.93 & 9.35 \\
& Rough grassland/herb & $\mathbf{0 . 4 1}$ & 0.64 & 0.24 & 0.17 \\
& Shrub, bush, creeper & $\mathbf{5 . 1 0}$ & 6.52 & 3.69 & 3.26 \\
& Tree & $\mathbf{6 5 . 8 5}$ & 62.74 & 67.53 & 62.64 \\
& Built environment & $\mathbf{1 9 . 4 5}$ & 17.43 & 18.61 & 24.57 \\
\hline
\end{tabular}

3.2 Assessment of the impact of the green-blue corridor and the sustainable small forest on regulation and maintenance LS: biodiversity

\subsubsection{Structural indicators}

There are 8,899 individuals of 113 species spread all over Benicalap District and 122 individuals of 11 species of street trees in the pilot projects. Within street trees species of 
NBS pilots there are $88.52 \%$ deciduous trees and $11.48 \%$ perennial trees. The area of pilot projects represents $0.57 \%$ of Benicalap District, where 11 species of seven families and six orders are concentrated (Table 5).

Table 5: Number of individuals, species, index of abundance $\left(\mathrm{I}_{\mathrm{TREES}}\right)$ and percentage of street trees species at district, street and pilot projects (actions) level.

\begin{tabular}{|c|c|c|c|c|c|c|c|}
\hline Order & District & Street & Itrees & Species & $\begin{array}{c}\text { District } \\
\%\end{array}$ & $\begin{array}{c}\text { Street } \\
\%\end{array}$ & $\begin{array}{c}\text { Pilot } \\
\%\end{array}$ \\
\hline Arecales & 1689 & 1 & 0.00 & Phoenyx dactylifera & 3.78 & 0.30 & 0.85 \\
\hline zales & & 1 & 01 & Yucca elephantipes & 2.86 & 2.38 & 0.85 \\
\hline \multirow{3}{*}{ Fabales } & \multirow{3}{*}{790} & & \multirow{3}{*}{0.01} & Ceratonia siliqua & 0.54 & 12.50 & 0.85 \\
\hline & & & & Cercis siliquastrum & 25.68 & 1.59 & 5.93 \\
\hline & & & & Robinia pseudoacacia & 4.63 & 1.47 & 0.85 \\
\hline \multirow{2}{*}{ Lamiales } & \multirow{2}{*}{1366} & \multirow{2}{*}{48} & \multirow{2}{*}{0.04} & Jacaranda mimosifolia & 27.72 & 9.58 & 33.05 \\
\hline & & & & Olea europaea & 2.59 & 23.68 & 7.63 \\
\hline & & 1 & 0.02 & Populus sp. & 3.54 & 1.92 & 0.85 \\
\hline \multirow{2}{*}{ Sapindales } & \multirow{2}{*}{1825} & \multirow{2}{*}{35} & \multirow{2}{*}{0.02} & Ailanthus altissima & 0.20 & 100.00 & 2.54 \\
\hline & & & & Melia azedarach & 29.97 & 7.27 & 27.12 \\
\hline Urticales & 33 & 23 & 0.70 & Ulmus pumila & 2.25 & 72.73 & 19.49 \\
\hline
\end{tabular}

Density of trees by street section is 0.1 , which means that the recommended distances [16] are not always respected (Table 5). Present number of street trees is two times smaller than it should. Recommended indicator has value of 0.2 for $100 \mathrm{~m}$ longitudinal transect, which means one tree at every five meters.

Size class distribution is applied specifically to street trees. In both pilot projects, semimature trees dominate $(68.12 \%, 50.00 \%)$, while senescent trees are very poor represented $(1.45 \%)$ or are missing $(0.00 \%)$ (Table 6$)$. The other two age classes are also unbalanced. According to Leff [18], the ideal percentages of street trees distribution are not respected ( $40 \%$ juvenile, $30 \%$ semi-mature, $20 \%$ mature and $10 \%$ senescent trees). In the pilot projects, there are almost double and more than double semi-mature trees than it should be $(30 \%)$. More juvenile trees are needed in both cases, as they revitalize the urban ecosystem. In the corridor, the percentage of mature trees reaches around $20 \%$. However, in the forest, the existing proportion $(29.17 \%)$ overpasses the recommendation $(20 \%)$. Our study results are opposite to McPherson et al. findings of cities of Inland Valley, California, where street inventories were characterized by higher percentage of young trees populations (55\%) [24]. The similitude appears for lower than ideal percentages of mature (18\%) and old $(5 \%)$ trees.

Present relative tree canopy cover of the corridor represents $69.20 \%$ of total area $\left(7,352 \mathrm{~m}^{2}\right)$, which is qualified as fair [18]. Present forest tree canopy cover is estimated as low $\left(24.40 \%\right.$ of total surface $\left(5,356 \mathrm{~m}^{2}\right)$ ) (Table 6). Low status sites investigated by Pauleit et al. [25] presented around 3\% of tree cover of $0.25 \mathrm{~km}^{2}$. Considering Ciutat Fallera's financial situation [13], we could it classify as low status neighbourhood.

\subsubsection{Biodiversity indicators}

The estimation of the values of post greening vegetation diversity shows a significant rise of these indicators in both actions. In the case of the green-blue corridor, Shannon-Wiener Index increases from 1.15 to 1.93 , which means that goes from an initial poor biodiversity level $\left(0.5<\mathrm{H}^{\prime}<1.5\right)$ to almost a good level $\left(2<\mathrm{H}^{\prime}<3\right)$ according to Agencia d'Ecologia 
Table 6: Community structure indicators of the current situation of street trees within project actions.

\begin{tabular}{llcc}
\hline Indicators & Canopy width (m) & $\begin{array}{c}\text { Green-blue } \\
\text { corridor }\end{array}$ & $\begin{array}{c}\text { Sustainable } \\
\text { small forest }\end{array}$ \\
\hline & Small size & 8 & \\
Street trees density (N. & Medium size & 2 & 0 \\
trees/50 m) & Big size & 0 & 0 \\
& Juvenile & 14.49 & 5 \\
& Semi-mature & 68.12 & 20.83 \\
Age diversity (\%) & Mature & 15.94 & 29.00 \\
& Senescent & 1.45 & 00.00 \\
Relative tree canopy (\%) & & 69.20 & 24.40 \\
\hline
\end{tabular}

Urbana de Barcelona [16] and evenness raises in 50\% (Table 7). Regarding the forest which, at present time, contains just one species (Ulmus pumila), post greening stage involves reaching a very good level of biodiversity $\left(3<\mathrm{H}^{\prime}<4\right)$ and a more equal species distribution (closer to value 1). According to Barker et al. [6], community's accessible green spaces, street trees and hedgerows are very likely to enhance biodiversity at micro scale.

Table 7: Diversity of vegetation species, strata diversity and habitats proportions before and after selecting the pilot projects to construct the green-blue corridor (action 3) and small sustainable forest (action 2).

\begin{tabular}{llcccc}
\hline & Diversity indices & \multicolumn{2}{c}{ Action 3 } & \multicolumn{2}{c}{ Action 2 } \\
& & $\begin{array}{c}\text { Pre- } \\
\text { greening }\end{array}$ & $\begin{array}{c}\text { Post- } \\
\text { greening }\end{array}$ & $\begin{array}{c}\text { Pre- } \\
\text { greening }\end{array}$ & $\begin{array}{c}\text { Post- } \\
\text { greening }\end{array}$ \\
\hline \multirow{3}{*}{ Vegetation } & Shannon-Wiener Index & 1.15 & 1.93 & $*$ & 3.07 \\
& Maximum diversity & 3.40 & 3.78 & $*$ & 4.13 \\
& Evenness & 0.34 & 0.51 & 0 & 0.74 \\
Strata & Shannon-Wiener Index & 0.97 & 0.99 & 0.56 & 0.69 \\
& Maximum diversity & 1.61 & 1.61 & 1.61 & 1.61 \\
& Evenness & 0.60 & 0.61 & 0.35 & 0.43 \\
\multirow{5}{*}{ Habitat cover } & Bare ground/turf grass & 7.43 & 9.18 & 74.60 & \\
& Rough grassland/herb & 0.04 & 0.41 & - & 80.00 \\
& Shrub, bush, creeper & 2.44 & 5.10 & - & \\
& Tree & 57.99 & 65.85 & $25.40 *$ & 20.00 \\
& Built environment & 32.09 & 19.45 & - & 0 \\
\hline
\end{tabular}

*At pre-greening stadia there is only a set of decrepit Ulmus pumilla.

When comparing the diversity of vegetation strata for pre and post greening stages, the increase in Shannon-Wiener Index (from 0.97 to 0.99) and evenness (from 0.60 to 0.61 ) is slight in the case of the corridor. Regarding forest, similar values are found (Shannon-Wiener Index rises from 0.56 to 0.69 and evenness from 0.35 to 0.43 ). This result can be explained by the fact that in the pre-greening stage, only two out of five types of habitats were identified (trees, $25.4 \%$ and bare ground/turf grass, 74.6\%), while, after the implementation of NBS, three categories of habitats, such as: bare ground and turf grass, rough grassland and herbs and shrubs, bushes and creeper plants are expected to increase around $80 \%$. This result is the 
estimation of the first year post greening. When trees reach their maturity, crown coverage is expected to be more than 70\%. In 2000, all sites of Merseyside, UK, the structural diversity (Shannon-Wiener Index) is 1.09 for a vegetation area which covers 8.31 ha [25].

Among the species of pilot project, five street tree species out of ten are identified as being suitable for the area. According to Leff [18], this means a fair degree of adaptability (50\%) to Valencia's climate and soil conditions. These species are: Mediterranean native species (Cercias siliquastrum, Ceratonia siliqua, Olea europaea), naturalized species, useful for inhabitants e.g. date palm (Phoenix dactylifera) and ornamental species cultivated for decorative purpose e.g. blue jacaranda (Jacaranda mimosifolia). All of them are present in the location of the corridor in the pre-greening stage.

\subsection{Assessment of the impact of the green-blue corridor and the sustainable} small forest on cultural LS

Fig. 3 shows the results of behavioural indicators of social interactions and physical activity measured before the implementations of NBS with Mohawk tool. Results on social interactions reveal that $34.77 \%$ of people were talking with each other or having other types of physical contact e.g. holding hands in the street part of corridor, $28.89 \%$ in the square part. And $29.93 \%$ persons interacted in the forest area. This can be explained by the fact that Carrer del Foc street and Plaza Regino Mas is four times smaller than forest area. Also, corridor's square presents some facilities, such as: bus stop, bars, restaurants, playgrounds and school, which leaded to casual encounters, reflected by the big percentage of neighborhood community who was passing through and having contact in the green-blue corridor. Also, Plaza Regino Mas has a smaller surface than forest. The small surface of forest was used mostly to walk dogs and pass through. According to Barker et al. [6], neighbourhood green spaces are likely to improve social interactions and enhance physical health of inhabitants. Regarding indicators of physical activity level, it can be seen that more than $80 \%$ of people were walking in the corridor's arena, while in the forest area were estimated almost $72 \%$. A percentage of $10.51 \%$ of vigorous people were crossing the forest area, while $2.65 \%$ were walking fast or running in corridor's street and $12.28 \%$ in the square part. Forest pilot project is a calmer open space, an isolated one with lower traffic than corridor, which is more dynamic and characterized by a big number of passing cars and noise. The creation of greenblue corridor and sustainable forest are expected to increase both social interactions and level of physical activity.

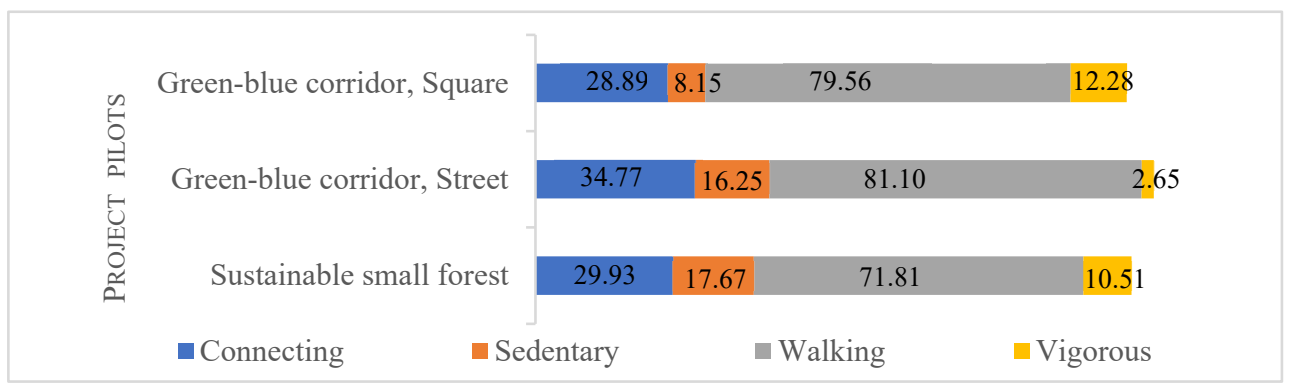

Figure 3: Values of behavioural KPIs for one week at sustainable small forest action and green-blue corridor action (street and square). Bar chart numbers represent percentages of people who are connecting and undertaking forms of physical activity. 
The indicators applied in this work are limited to the pre-greening stage of two small scale pilot projects with poor impact at district scale. Further studies should consider the whole range of UGI elements, including agriculture land which was not part of the analysed case studies.

\section{CONCLUSIONS}

The article reviews the applicability of green infrastructure indicators at micro scale or street scale and tests the usefulness of a set of these indicators to design and evaluate the effects of NBS implementation and the improvement of green infrastructure. Not only structure indicators are used to assess UGI condition, but also indicators linked to regulation and cultural landscape services, especially to biodiversity and people behaviour.

The assessment of regulation services, in terms of structural indicators, suggests that none of the sites where the pilot projects will be developed meet the recommended density of street trees and tree age diversity. Tree canopy is fair in the green-blue corridor and low in the sustainable small forest for the pre-greening stage. Concerning biodiversity indicators, they allow the prediction of the post-greening stage situation, showing an increase in ShannonWiener Index and evenness, which is especially significant for the sustainable small forest. The assessment of the cultural services connected to social interactions and physical activity indicates that the green-blue corridor shows slightly higher values than the sustainable small forest does at the pre-greening stage.

This paper demonstrates that UGI indicators are a helpful method, complementary to cartography, in order to assess design alternatives and select the most sustainable future strategies to be implemented at urban scale. By unifying green infrastructure indicators and methods of measurement from three complementary domains, such as ecology, forestry and social-cultural sciences, this work contributes to a better understanding of UGI as a sustainable tool and to make better informed decisions regarding its implementation in urban planning and management.

The results of this study show how urban green infrastructure elements can be used to integrate urban and agroecosystems. Working in a space of opportunity in its transition between city and orchard, new elements of the urban green infrastructure can be integrated and used to extend the network and solve the interface between agriculture and city, contributing thus to deliver a wide range of ecosystem services' in both rural and urban settings, the purpose of the green infrastructure.

\section{ACKNOWLEDGEMENTS}

This work was supported by the European Union's Horizon 2020 research and innovation programme under the project Green Cities for Climate and Water Resilience, Sustainable Economic Growth, Healthy Citizens and Environments with reference 730283. We are grateful to Las Naves, Ayuntamiento de Valencia and Bipolaire for data collaboration.

\section{REFERENCES}

[1] De Ridder, K. et al., An integrated methodology to assess the benefits of urban green space. Science of the Total Environment, 334-335, pp. 489-497, 2004.

DOI: $10.1016 /$ j.scitotenv.2004.04.054.

[2] European Union, Urban GI components inventory milestone 23. Green Surge Project, 2013. www.greensurge.eu. Accessed on: 25 Sep. 2018. 
[3] European Union, Horizon 2020. EKLIPSE Expert Working Group on Nature-based Solutions, An impact evaluation framework to guide the evaluation of nature-based solutions projects. (Draft) 19, 2016. www.eklipse-mechanism.eu/apps/Eklipse_data/ website/EKLIPSE_Report1-NBS_FINAL_Complete-08022017_LowRes_4Web.pdf. Accessed on: 12 Mar. 2020.

[4] Grow Green, Grow Green, a partnership for greener cities to increase liveability, sustainability and business opportunities. www.Growgreenproject.eu. Accessed on: 4 Mar. 2020.

[5] European Commission, Strategic green infrastructure and ecosystem restoration. Geospatial methods, data and tools, 2019. www.ec.europa.eu/environment/nature/ ecosystems/index_en.htm. Accessed on: 1 Apr. 2020.

[6] Barker, A. et al., Understanding green infrastructure at different scales: A signposting guide. University of Manchester: Manchester, 2019.

DOI: 10.13140/RG.2.2.26366.95045.

[7] Tudorie, C.M., Gielen, E., Valles-Planells, M. \& Galiana, F., Urban green indicators: A tool to estimate the sustainability of our cities. Urban Agriculture 2018 1st International Conference on Urban Agriculture and City Sustainability, New Forest, UK. 2019. DOI: 10.2495/DNE-V0-N0-1-11.

[8] Pakzad, P. \& Osmond, P., Developing a sustainability indicator set for measuring green infrastructure performance. Procedia: Social and Behavioral Sciences, 216, pp. 68-79, 2016. DOI: 10.1016/j.sbspro.2015.12.009.

[9] Termorshuizen, J.W. \& Opdam, E.P., Landscape services as a bridge between landscape ecology and sustainable development. Landscape Ecology, 24, pp. 10371052, 2009. DOI: 10.1007/s10980-008-9314-8.

[10] Valls-Donderis, P., Vallés, M.C. \& Galiana, F., Criteria and indicators for sustainable forestry under Mediterranean conditions applicable in Spain at the forest management unit scale. Forest Systems, 24(1), e004, 2015. DOI: 10.5424/fs/2015241-05542.

[11] Vallés-Planells, M., Galiana, F. \& Van Eetvelde, V.A., Classification of landscape services to support local landscape planning. Ecology and Society, 19(1), p. 44, 2014. DOI: $10.5751 /$ ES-06251-190144.

[12] Haines-Young, R. \& Potschin, M., Common International Classification of Ecosystem Services (CICES) V5.1 Guidance on the Application of the Revised Structure, UK, 2017. https://cices.eu/content/uploads/sites/8/2012/07/CICES-V43_Revised-Final_ Report_29012013.pdf. Accessed on: 25 Mar. 2020.

[13] Ayuntamiento de Valencia, Oficina de estadística, Barrio Ciutat Falera. www.valencia.es/ayuntamiento/webs/estadistica/inf_dtba/2019/Distrito_16_Barrio_ 2.pdf. Accessed on: 16 Mar. 2020.

[14] Clément, J., Manifesto del tercer paisaje, Gustavo Gili, 2007.

[15] Ayuntamiento de València, Propuesta de plan especial verde para la ciudad de Valencia, Valencia, Ayuntamiento de Valencia, 181, unpublished document, 1992.

[16] Agencia d'Ecología Urbana de Barcelona, Plan de indicadores de sostenibilidad urbana de Vitoria-Gasteiz. Ayuntamiento de Vitoria-Gasteiz, 2010.

www.vitoria-gasteiz.org/wb021/http/contenidosEstaticos/adjuntos/es/89/14/ 38914.pdf. Accessed on: 10 Mar. 2020.

[17] Gering, L.R. \& May, D.M., The relationship of diameter at breast height and crown diameter for four species groups in Hardin County, Tennessee. Southern Journal of Applied Forestry, 19(4), pp. 177-181, 1995. DOI: 10.1093/sjaf/19.4.177. 
[18] Leff, M., The Sustainable Urban Forest a Step-by-Step Approach, Davey Institute/ USDA Forest Service USFS Philadelphia Field Station, 2016. www.itreetools.org/ resources/content/Sustainable_Urban_Forest_Guide_14Nov2016.pdf. Accessed on: 5 Mar. 2020.

[19] Braun-Blanquet, J., Plant Sociology, McGraw-Hill: New York, p. 539, 1932.

[20] Krebs, C.J., Species diversity measures. Ecological Methodology, Harper and Row Inc.: New York, 1989.

[21] Handley, J.F., Nature in the Urban Environment: City Landscape, Grove Cresswell, Butterworths: London, pp. 47-59, 1988.

[22] Benton, J.S., Anderson, J., Cotterill, S., Hunter, R.F., Pulis, M. \& French, D.P., Method for observing physical activity and wellbeing (MOHAWK): Observation Manual. University of Manchester: Manchester, 2018.

[23] World Health Organization, Global strategy on diet, physical activity and health. www.who.int/dietphysicalactivity/factsheet_adults/en/. Accessed on: 2 Apr. 2020.

[24] McPherson, E.G., van Doorn, N. \& de Goede, J., Structure, function and value of street trees in California, USA. Urban Forestry and Urban Greening, 17, pp. 104-115, 2016. DOI: 10.1016/j.ufug.2016.03.013.

[25] Pauleit, S., Roland Ennos, R. \& Golding, Y., Modeling the environmental impacts of urban land use and land cover change: A study in Merseyside, UK. Landscape and Urban Planning, 71, pp. 295-310, 2005. DOI: 10.1016/j.landurbplan.2004.03.009. 